\title{
ROLA ZASOBÓW WEWNĘTRZNYCH I ZEWNĘTRZNYCH W MODELU RELACYJNEJ INKLUZJI SPOŁECZNEJ
}

Streszczenie: W niniejszym artykule odniesiono się do jednego z wielu ważnych zagadnień, jakim może być problem wykluczenia społecznego. Zastanawiając się nad rozwiązaniami pozwalającymi na minimalizowanie zagrożeń generujących wykluczenie społeczne, a jednocześnie poszukując czynników i sposobów ułatwiających proces włączenia społecznego, podjęto próbę opracowania modelu relacyjnej inkluzji społecznej. Należy wyraźnie zaznaczyć, że omawiane kwestie nie dotyczą wyłącznie osób z niepełnosprawnością, a nawet dużym błędem byłoby utożsamianie niepełnosprawności z wykluczeniem społecznym. Jest to zbyt daleko idące, stereotypowe uproszczenie. Bezsprzecznie należy obalać fałszywe wyobrażenia, które niestety ciągle są obecne w świadomości społecznej. Rozważania w obszarze ekskluzji i inkluzji odniesiono do szerokiej grupy osób wykluczonych, do której mogą również należeć osoby z niepełnosprawnością.

Słowa kluczowe: inkluzja, ekskluzja, zasoby wewnętrzne, zasoby zewnętrzne, relacyjny, wsparcie społeczne

\section{Wprowadzenie}

Sytuacja osoby z niepełnosprawnością, funkcjonującej w określonej przestrzeni społecznej, jest niewątpliwie zagadnieniem wielowymiarowym, co wynika zarówno z faktu złożoności problemów dotyczących każdego człowieka, w tym także z niepełnosprawnością, jak też z definicji samego określenia „przestrzeń społeczna”, które jest złożone i niejednorodne. Już jego dualizm wyznacza niemały obszar interpretacyjny. Tak więc zagadnienie osoby z niepełnosprawnością w przestrzeni społecznej obejmuje bardzo szeroki zakres problemów zarówno w ujęciu teoretycznym, jak i praktycznym.

W niniejszym artykule odniesiono się wyłącznie do jednego $\mathrm{z}$ wielu zagadnień istotnych dla osoby z niepełnosprawnością, jakim może być problem wykluczenia społecznego. Zastanawiając się nad rozwiązaniami pozwalającymi na 
minimalizowanie zagrożeń generujących wykluczenie społeczne, a jednocześnie poszukując czynników i sposobów ułatwiających proces włączenia społecznego, podjęto próbę opracowania modelu relacyjnej inkluzji społecznej.

Należy wyraźnie zaznaczyć, że omawiane kwestie nie dotyczą wyłącznie osób z niepełnosprawnością, a nawet dużym błędem byłoby utożsamianie niepełnosprawności z wykluczeniem społecznym. Jest to zbyt daleko idące, stereotypowe uproszczenie. Bezsprzecznie należy obalać fałszywe wyobrażenia, które ciągle niestety są obecne w świadomości społecznej. Rozważania w obszarze ekskluzji i inkluzji odniesiono do szerokiej grupy wykluczonych, do której mogą również należeć osoby z niepełnosprawnością.

\section{Uwarunkowania wykluczenia społecznego}

W ostatnich dekadach kwestie uwarunkowań wykluczenia społecznego są często poruszane. Tematyka ta jest obecna głównie w naukach społecznych (pedagogice, polityce społecznej, psychologii, pracy socjalnej), choć nie tylko. Budzi również powszechne zainteresowanie, ponieważ społeczeństwo, w jakim żyjemy, jest dzisiaj nie tylko społeczeństwem nierówności, ale także niepewności (Beck 2012). Zjawiska te wzajemnie się nakładają i uzupełniają, generując coraz więcej obszarów i grup osób zagrożonych wykluczeniem społecznym. Współcześnie zauważamy więc, że paradoksalnie wraz z rozkwitem procesów demokratyzacji społeczeństwa wzrasta liczba źródeł społecznego wykluczenia.

Wykluczenie jako termin naukowy pojawiło się w badaniach z zakresu nauk społecznych dosyć późno - w latach 6o. ubiegłego wieku. Samo pojęcie wykluczenia społecznego wywodzi się z języka francuskiego, jest tłumaczeniem nazwy exclusion. Według Tadeusza Kowalaka jego najwłaściwszy przekład to: „wykluczenie ze społeczeństwa zorganizowanego" (Kowalak 1998, s. 29). Na początku lat 90. XX wieku pojęcie wykluczenia społecznego było wykorzystywane w zastępstwie pojęcia ubóstwa, pojawiającego się w kontekście przeobrażeń społeczno-politycznych, i zastąpiło używane wcześniej pojęcie ubóstwa lub podklasy (underclass).

Według Anthony’ego Giddensa pojęcie wykluczenia społecznego ma zastosowanie, gdy jest mowa o nowych źródłach nierówności społecznych. „Wykluczenie odnosi się do sytuacji, w której jednostki pozbawione zostają możliwości pełnego uczestnictwa w społeczeństwie. Wykluczenie jest pojęciem szerszym niż pojęcie podklasy i ma nad nim tę przewagę, że akceptuje aspekt procesu mechanizmów wykluczenia" (Giddens 2004, s. 346). Według tego badacza istnieją różne formy wykluczenia:

- ekonomiczne,

- polityczne,

- społeczne.

Mechanizmy wykluczenia społecznego są różnorodne. Janusz Czapiński wskazuje 11 czynników powodujących wzrost zagrożenia marginalizacją (Czapiński 
200o, s. 54-92). Syntetyzując, można wskazać, że są nimi: podeszły wiek, ubóstwo, zamieszkiwanie na terenach wiejskich, niskie wykształcenie (własne i rodziny pochodzenia), uzależnienia, konflikty z prawem, poczucie dyskryminacji, bezrobocie i niepełnosprawność. Czynniki te stanowią jednocześnie korelaty lub wyznaczniki różnych rodzajów wykluczenia społecznego, do których należą:

- wykluczenie strukturalne - najsilniej powiązane z miejscem zamieszkania i wykształceniem;

- wykluczenie fizyczne - zwykle wiązane z podeszłym wiekiem i złym stanem zdrowia;

- wykluczenie normatywne, które wyznaczają głównie różne uzależnienia, konflikty z prawem, ale także samotność lub poczucie dyskryminacji związanej z odmiennością narodową, przekonaniami, a nawet wyglądem;

- wykluczenie materialne - powiązane z bezrobociem i ubóstwem,

- wykluczenie cyfrowe - związane z ograniczonym przez różne czynniki dostępem do nowych technologii, w tym głównie do internetu.

Ważnym elementem wyjaśniającym zjawisko wykluczenia jest identyfikowanie zasadniczych czynników odpowiedzialnych za sytuację życiową ludzi dotkniętych tym procesem. Jolanta Grotowska-Leder wyróżnia następujące problemy, przyczyniające się do wykluczenia społecznego:

1) biologiczne - będące zwykle konsekwencją ograniczenia własnych zdolności, stanu zdrowia, sprawności (np. u niepełnosprawnych, chorych, upośledzonych);

2) rynkowe - wiążące się z konkurencyjnością na rynku pracy, a także podażą i popytem na określone typy wykształcenia czy zawodu (np. niskie wykształcenie, niepopularny zawód, nieodpowiednie kwalifikacje);

3) kulturowe - wynikające z odmiennych wzorców, obyczajów, wartości i przekonań (np. przynależność do mniejszości religijnej, etnicznej, problemy psychologiczne przekładające się na funkcjonowanie, np. u osób ze skłonnościami do depresji, uzależnień, z zaburzeniami charakterologicznymi, doświadczających braku bezpieczeństwa i miłości) (Grotowska-Leder, Faliszek 2005, s. 28-29).

Wykluczenie społeczne jest niewątpliwie pojęciem niejednorodnym, obejmującym złożoną, zmienną klasę zjawisk. Zbiorowość osób wykluczonych jest zróżnicowana zarówno zewnętrznie, jak i wewnętrznie. A poza tym mamy do czynienia z kilkoma nakładającymi się wymiarami wykluczenia, spośród których cztery są podstawowe:

1) wyłączenie z aktywności zawodowej (bezrobocie, niepełnosprawność),

2) wyłączenie z konsumpcji (ubóstwo),

3) wyłączenie ze społeczności (samotność),

4) wyłączenie z mechanizmów wpływu i władzy (marginalizacja kulturowa i polityczna) (Grotowska-Leder, Faliszek 2005, s. 28-29).

Osoby, które teoretycznie spełniają wyżej wymienione kryteria, najczęściej: 
- żyją w niekorzystnych warunkach ekonomicznych (ubóstwo materialne),

- zostają dotknięte niekorzystnymi procesami społecznymi,

- nie zostały wyposażone w kapitał życiowy, umożliwiający im osiągnięcie odpowiedniej pozycji społecznej czy poziomu kwalifikacji itp.,

- nie posiadają dostępu do instytucji pozwalających na wyposażenie w kapitał życiowy, jego rozwój i pomnażanie,

- doświadczają przejawów dyskryminacji,

- posiadają cechy utrudniające im korzystanie z powszechnych zasobów społecznych ze względu na istnienie niesprawności, uzależnienia albo innych cech indywidualnych,

- są celem niszczącego działania innych osób, np. przemocy, szantażu. W tej grupie, opierając się na wynikach diagnozy społecznej, obserwuje się: wykluczenie społeczne strukturalne, które wiąże się z miejscem zamieszkania oraz niskim wykształceniem własnym i ojca, skorelowanymi z determinowanymi przez te cechy dochodami gospodarstwa domowego poniżej ubóstwa; wykluczenie społeczne fizyczne, związane z wiekiem, inwalidztwem oraz $\mathrm{w}$ mniejszym stopniu wykształceniem, natomiast negatywnie korelujące z bezrobociem oraz ubóstwem; wykluczenie normatywne, dotyczące osób uzależnionych, samotnych wchodzących w konflikt z prawem (por. Czapiński, Panek 2014, s. 269-270).

Powołując się na zaprezentowaną charakterystykę, można wyodrębnić grupę osób szczególnie podatną na wykluczenie społeczne. Zauważa się, że są to głównie:

- dzieci i młodzież ze środowisk zaniedbanych,

- dzieci wychowujące się poza rodziną,

- kobiety samotnie wychowujące dzieci,

- kobiety pozostające poza rynkiem pracy,

- ofiary patologii życia rodzinnego,

- osoby o niskich kwalifikacjach,

- osoby bezrobotne,

- żyjący w bardzo trudnych warunkach mieszkaniowych,

- niepełnosprawni i chronicznie chorzy,

- osoby chorujące psychicznie,

- starsze osoby samotne,

- opuszczający zakłady karne,

- imigranci,

- osoby należące do mniejszości etnicznych.

Proces wykluczenia dokonuje się w określonym kontekście społecznym, ale obejmuje istotne uwarunkowania osobowe zarówno wykluczających, jak wykluczonego. Każda $\mathrm{z}$ form wykluczenia jest zatem pochodną innych, ale warto zastanowić się nad tym, jak ów złożony mechanizm „spychania na margines życia społecznego” funkcjonuje, co jest w nim najistotniejsze (pierwotne), a co najmniej ważne (wtórne), w odniesieniu do specyfiki różnych kategorii osób (i grup), w tym także z różnego 
rodzaju niepełnosprawnościami, zagrożonych wykluczeniem społecznym. Istnieje więc potrzeba podjęcia szczegółowych analiz procesu wykluczenia z perspektywy poszczególnych jednostek.

Wyniki przeprowadzonych badań, głównie tych o charakterze kognitywnym, wyraźnie akcentują istnienie zależności pomiędzy wycofaniem się z życia, biernością, brakiem celu i sensu egzystencji jednostki a innymi problemami społecznymi zarówno na poziomie indywidualistycznym, jak i supraindywidualistycznym. Ten bliski związek upoważnia do poszukiwania modelu zapobiegania zjawiskom ekskluzji, marginalizacji, pauperyzacji, a więc optymalnego sposobu „włączania społecznego" (Bałandynowicz i in. 2015, s. 5).

\section{Zjawisko inkluzji społecznej}

Antidotum na zjawisko wykluczenia społecznego odnajdujemy w koncepcjach inkluzji społecznej. Definiowana jest ona jako proces włączania jednostek, grup czy kategorii społecznych. W ostatnich latach, podobnie jak zjawisko ekskluzji, również ten termin pojawia się dosyć często, i to głównie w kontekście konieczności podjęcia działań o charakterze inkluzyjnym. W towarzystwie inkluzji funkcjonują określenia: „włączanie” (do otwartego środowiska), „włączanie edukacyjne” (strategia systemu edukacyjnego) czy „edukacja włączająca” (oddziaływania edukacyjne).

Na użytek prowadzonych rozważań określenie „włączanie społeczne” odnoszę do pełnego uczestnictwa jednostek w życiu społecznym. Taka interpretacja jest bliska pedagogice społecznej, na gruncie której bardzo mocno akcentuje się znaczenie relacji jednostka - środowisko. Już Helena Radlińska podkreślała konieczność prowadzenia takich działań, które pozwolą „rozbudzić w każdej jednostce poczucie przynależności do społeczeństwa, współodpowiedzialności za gromadę" (Radlińska 1935, s. 18). Przedstawiony za Radlińską kierunek działania w pełni odpowiada współczesnym potrzebom inkluzji społecznej, która koncentruje się na osobach zagrożonych wykluczeniem społecznym bądź już funkcjonujących na marginesie życia społecznego. O efektywności procesu inkluzji możemy mówić wówczas, jeżeli osoby żyjące w określonej przestrzeni społecznej w pełni uczestniczą w życiu społecznym i czują się zintegrowane z daną społecznością.

W obszarze działania kryjącego się pod nazwą „inkluzja społeczna” należy podkreślić te rozwiązania, które zmierzają do ponownego bądź pierwotnego włączenia danej osoby w nurt życia społecznego. Istotą inkluzji jest dążenie do aktywnego udziału danej jednostki (na miarę jej możliwości i potencjału) w różnych obszarach życia społecznego, a jej podstawowym sukcesem jest trwałe społeczne włączenie osób dotychczas marginalizowanych. Jest to proces ciągły, wymagający nieustannej uwagi, namysłu, czujności i wrażliwości społecznej. Nie jest też możliwe osiągnięcie stanu jednoznacznie finalnego, gdyż w każdej nowej sytuacji mogą pojawić się czynniki, które wywołają ekskluzję osób dotychczas zintegrowanych w życiu społecznym. Tak naprawdę nigdy do końca nie jesteśmy w stanie przewidzieć 
wszystkich bodźców wspierających bądź ograniczających efektywność procesu inkluzji społecznej.

Lista czynników jej sprzyjających jest znacząca i różnorodna. Podobnie jak czynników generujących ekskluzję społeczną. Zdecydowanie lepiej skierować aktywność na poszukiwanie bodźców wspierających niż tych utrudniających włączanie społeczne.

Poszukując odpowiedzi na pytanie, od czego zależy efektywność inkluzji społecznej, znajdujemy wiele istotnych czynników, które najogólniej można sprowadzić do dwóch zasadniczych grup: zasobów wewnętrznych i zewnętrznych.

\section{Zasoby wewnętrzne i zewnętrzne a proces inkluzji społecznej}

Osobom wykluczonym społecznie najczęściej towarzyszą negatywne emocje i przekonanie o nieumiejętności poradzenia sobie w sytuacji, w jakiej się znaleźli (Fidelus 2012). Stevan E. Hobfoll zauważył, że „radzenie sobie jest konceptualizowane jako działanie człowieka w stresujących okolicznościach, a zwłaszcza w momencie doświadczania największego stresu" (Hobfoll 2006, s. 113). Niewątpliwie na strategię radzenia sobie w takich okolicznościach ma wpływ wiele czynników, tak wewnętrznych (osobowościowych), jak też zewnętrznych (środowiskowych). „Negatywne emocje i stres uruchamiają procesy adaptacyjne, polegające na aktywizacji zasobów jednostki, takich jak optymizm, poczucie kontroli czy wysoka samoocena, a także mechanizmów obronnych i zaradczych, ukierunkowanych zarówno na rozwiązanie zaistniałych w związku ze zmianą problemów, jak i na poradzenie sobie z negatywnymi emocjami wywołanymi przez zmianę" (Lachowicz-Tabaczek 2004, s. 55). Zasoby wewnętrzne dotyczą uwarunkowań związanych z samą osobą włączaną. Obejmują umiejętności oraz cechy, które same w sobie są cenione lub konieczne do zdobycia innych dóbr, potrzebnych do przetrwania i podniesienia jakości życia człowieka. Umiejętności to kompetencje społeczne i zawodowe, a cechy to między innymi: samoocena, optymizm, poczucie własnej skuteczności. Zasoby wewnętrzne znajdują się w posiadaniu Ja lub pozostają w sferze Ja. Obejmują: świadomość własnej wartości, posiadanych kompetencji, w tym zawodowych, poczucie sensu życia, optymizm. Zasoby zewnętrzne znajdują się poza granicami Ja, nie są jego własnością. Należą do nich głównie: wsparcie społeczne, zatrudnienie, status ekonomiczny. Osoby wykluczone społecznie najczęściej nie posiadają wymienionych zasobów wewnętrznych. A nawet jeśli je mają, to nie są świadome ich posiadania i możliwości wykorzystania. Pojawia się więc kwestia diagnozowania i wydobywania zasobów wewnętrznych, a także uruchamiania i wzmacniania zasobów zewnętrznych. Taki dychotomiczny, może według niektórych uproszczony, podział wykorzystywało wielu badaczy (Hobfoll, Walfisch 1984, s. 87-100).

Do grupy zasobów wewnętrznych należą między innymi: samoakceptacja, akceptacja innych, stygmatyzacja, optymizm, poczucie własnej skuteczności, satysfakcja z życia, samoocena, wolność emocjonalna, samoświadomość (refleksyjna, 
osobowa, zewnętrzna, obronna), postawa wobec przyszłości. Grupa czynników zwiększających szansę na powodzenie procesu inkluzji związana jest z osobą samego włączającego. Z pewnością należy do niej zaliczyć: wiarę we własne możliwości, odpowiedni poziom samooceny, samokontroli, niski poziom lęku psychicznego, umiejętność rozwiązywania problemów, cierpliwość, wytrwałość, poczucie sensu życia. Ważna jest znajomość siebie, swoich pozytywnych i negatywnych stron. W tym kontekście można zaakcentować problem związany z poczuciem tożsamości. Proces inkluzji uzależniony jest od stanu związanego z odrzucaniem bądź utrwalaniem tożsamości osoby wykluczonej. Istotne jest „przedefiniowanie obrazu siebie i własnej roli w społeczeństwie (grupach socjalizujących)” (Pytka 2010, s. 41), czego efektem będzie myślenie o sobie nie jako o osobie żyjącej na marginesie życia społecznego, ale z perspektywy równoprawnego członka danej społeczności. W przeorganizowaniu tożsamości z pewnością pomocne są wszelkie działania, których zadaniem jest „wykorzystanie tkwiących w człowieku potencjałów kreacyjnych w celu adekwatnego readaptowania go do warunków społecznych, by mógł on w innowacyjny, ale akceptowalny społecznie sposób rozwiązywać sytuacje problemowe" (Konopczyński 2010, s. 104). W procesie budowania nowej tożsamości uzupełnieniem są akceptujące, wzmacniające, a więc w konsekwencji włączające postawy społeczne. Bez społecznej akceptacji nie są możliwe zmiany tożsamościowe żadnej osoby. Dlatego też w procesie tym ogromną rolę odgrywają z jednej strony praca wspierająca rozwój struktur poznawczych i twórczych, z drugiej zaś - wsparcie i reakcje społeczne potwierdzające przeobrażenia w funkcjonowaniu i realizacji ról społecznych przez osobę wykluczoną. $Z$ tego też powodu działania o charakterze inkluzyjnym wobec osób wykluczonych muszą koncentrować się na doświadczaniu przez nie sytuacji związanych z poczuciem sensu życia, kształtowaniu umiejętności zastępowania agresji, zdobywaniu przeświadczenia o możliwości samodzielnego funkcjonowania w życiu społecznym. Wdrażanie określonych zachowań powinno służyć rozwojowi pozytywnego obrazu własnej osoby, zwiększaniu samoakceptacji i nabywaniu umiejętności w zakresie radzenia sobie z trudnymi sytuacjami. Kształtowanie kompetencji życiowych musi być podstawą wszelkich programów o charakterze inkluzyjnym, służących przygotowaniu człowieka do życia. Szczególne znaczenie w sytuacjach trudnych przypisuje się mechanizmowi samoskuteczności. Uważa się, że poczucie efektywności własnych działań wpływa na decyzję o podjęciu się określonego zadania lub przedsięwzięcia, a wysiłek i wytrwałość w działaniu oraz wysoka jakość reakcji emocjonalnych występują zarówno przed planowanymi zadaniami, jak też w ich trakcie. Człowiek, aby móc skutecznie działać, musi posiadać odpowiednie umiejętności i bodźce do podejmowania wyzwań. Jeżeli jednostce brakuje poczucia skuteczności, to nie potrafi ona działać efektywnie nawet wtedy, gdy wie, jak powinna postępować. Istnieje prawdopodobieństwo, że ludzie, którzy mają wątpliwości co do swoich możliwości, w obliczu trudności będą minimalizowali wysiłki bądź zrezygnują $\mathrm{z}$ nich całkowicie, a ponadto będą silnie pobudzeni emocjonalne, podczas gdy 
osoby z silnym poczuciem skuteczności w takich sytuacjach zwiększą starania, by podołać jeszcze większym wyzwaniom (Bandura 1982).

Analizowane zasoby mają wspólne właściwości, takie jak charakter zapisanych i wytworzonych w człowieku doświadczeń, umiejętności, przekonań i powiązanych z nimi procesów poznawczo-ewaluacyjnych.

W procesie społecznego włączania należy uszanować możliwości rozwojowe jednostki oraz jej godność, gdyż u osoby, która spotyka się z wewnętrzną akceptacją i szacunkiem, następuje odzyskanie wiary w poprawę własnej sytuacji oraz wzrasta poziom realizacji potrzeby hubrystycznej. Musi ona nabyć nowe doświadczenia, a porażki i sytuacje kryzysowe nie powinny być dla niej obciążeniem. Nowe satysfakcjonujące przeżycia posiadają istotne walory edukacyjne, gdyż wyzwalają motywację i myślenie w kierunku zmiany, która w dużym stopniu zależy od samej jednostki. W warunkach inkluzji człowiek powinien mieć szansę na nabycie: zaufania do samego siebie, poczucia własnej wartości, zdolności do radzenia sobie z wiedzą i umiejętnościami oraz adaptacyjności i plastyczności jako alternatywnych sposobów rozwiązywania problemów.

Natomiast wśród zasobów zewnętrznych osoby wykluczonej społecznie można wyróżnić dwie grupy. Pierwsza związana jest z czynnikami tkwiącymi w środowisku włączającym (kapitały społeczny, kulturowy, ekonomiczny). Druga obejmuje czynniki związane z kompetencjami osób, które z racji zawodu bądź działań $\mathrm{w}$ ramach wolontariatu pracują $\mathrm{z}$ osobami wykluczonymi społecznie. W działaniach wspierających osoby wykluczone społecznie wszelkie podejmowane prace powinny zmierzać do przemiany osobowościowej człowieka. Wtedy nauczyciel, wychowawca, opiekun bądź pracownik socjalny nie przyjmują roli specjalisty usuwającego problemy, lecz prowadząc określone zajęcia, wypełniają funkcje inicjatora, konsultanta i doradcy. Dbają, aby osoba w procesie sprawczym dokonywała wartościowych wyborów i pokonywała własne ograniczenia, czyli skupiała się na zabiegach pozwalających na realizację potrzeby wzrostu i integralnego rozwoju.

Zasoby zewnętrzne obejmują różnorodne formy wsparcia społecznego. Wiąże się ono z istnieniem sieci społecznej, czyli obecności powiązań jednostki z innymi ludźmi. Istotną rolę odgrywa subiektywna percepcja, będąca podstawą wartościowania jednostki. W sytuacji kryzysowej osoby z tak zwanej sieci społecznej nie zawsze mogą być jej świadome i przygotowane do udzielenia określonego wsparcia lub osoba w traumie może oczekiwać innego rodzaju pomocy, niż jest jej oferowany. Rodzina i przyjaciele są z reguły naturalnym środowiskiem wsparcia w trudnej sytuacji, ze względu na możliwość niwelowania wstrząsów i wykazywania zainteresowania oraz z powodu zasobów gromadzonych w procesie uspołeczniania jednostki (Bifulco 2007). Ogromnego znaczenia nabiera jednak wsparcie w grupach samopomocowych, gdzie można znaleźć ludzi połączonych wspólnym problemem życiowym, a relacje oparte są na wzajemnym zaufaniu, życzliwości, akceptacji, podobnych doświadczeniach i dyskrecji. Samo należenie do grupy wsparcia okazuje się istotnym wyznacznikiem odporności na sytuacje urazowe (Pospiszyl 2003). 
Wsparcie społeczne obejmuje cztery grupy uwarunkowań (Sęk, Cieślak 2006) i analizowane jest jako:

- wsparcie emocjonalne, oparte na empatii i zaufaniu, którego podstawowym zadaniem jest redukcja lęku i strachu;

- wsparcie instrumentalne, oparte na zachowaniach pomocniczych, które bezpośrednio odpowiadają na potrzeby jednostki, udzielane przez sieć organizacji lokalnych zarówno publicznych, jak i pozarządowych;

- wsparcie informacyjne, oparte na łatwym dostępie do informacji dotyczących sposobów radzenia sobie z problemami, a także organizacji mogących udzielić różnego rodzaju pomocy;

- wsparcie oceny, zawierające informacje ważne dla samooceny lub porównań społecznych.

Wsparcie społeczne rodzi się z poruszeń moralnych i motywacji solidarnościowych wielu bezinteresownych osób oraz instytucji i ich akcji społecznych oraz z podmiotowo-osobowego zaangażowania jednostek wrażliwych społecznie. Wsparcie funkcjonalne odnosi się do organizacji, jakości i motywacji wszelkich akcji społecznych, podczas których szansę realizacji ma określona idea wsparcia.

Istnieje różnego rodzaju wsparcie funkcjonalne:

- Środowiskowe - polegające na tworzeniu środowiska włączającego (inkluzja). Włączanie potrzebuje zmiany społecznie negatywnych postaw wobec różnych grup wykluczonych.

- Organizacyjne - obejmujące rozwiązywanie różnych problemów osób wykluczonych w konkretnych sytuacjach życiowych. Ważne są tu postawy opiekunów i osób podejmujących się niesienia pomocy (tak zwanym Innym) oraz działania społeczne, w tym interwencyjne, edukacyjne, adaptacyjne, terapeutyczne, socjoterapeutyczne. Chodzi tu o pierwszy ruch w kierunku inkluzji.

- Wyjaśniające - będące koniecznym elementem życia społecznego i rodzinnego na terenie danej jednostki administracyjnej. Za przykład może posłużyć wolontariat jako źródło wsparcia i łącznik między potrzebami osób niezaradnych życiowo lub/i niepełnosprawnych a wydolnością służb administracyjnych.

- Emocjonalne - mające na celu wzbudzanie pozytywnych emocji i uczuć (poczucie jedności, przynależności i wspólnoty, wzrost świadomości „bycia dla”, powstawanie przyjaźni, zdrowych relacji, komunikacji, rywalizacji itp.). Obejmuje ono też redukcję emocji negatywnych, takich jak: niepokój, lęk, gniew, stres, żal, odrzucenie, pretensje, bunt.

- Instrumentalne - wyrażające się w informowaniu o konkretnych sposobach zachowań i działań niezbędnych do zmiany trudnej sytuacji.

- Informacyjne - rozumiane jako doradzanie, dostarczanie fachowej informacji, przydatnej $\mathrm{w}$ radzeniu sobie $\mathrm{z}$ trudną sytuacją, $\mathrm{w}$ celu zaradzenia przeciwnościom i zaistniałym negatywnym sytuacjom. 
- Wartościująco-kreatywne - wykorzystywane w celu podwyższenia poczucia własnej wartości, jako pomoc w przewartościowaniu własnej samooceny, wzmocnieniu godności własnej i drugiej osoby (rodziny, dzieci).

- Moralne - popierające konkretny wysiłek słowem, zachętą, potwierdzeniem, zadowoleniem, czynem, doradztwem i jakąkolwiek formą uaktywnienia (Zacharuk 2008).

Człowiek szukający wsparcia oczekuje szacunku ze strony grup i środowisk wspólnotowych jako samodzielny i pełnowartościowy byt personalistyczny oraz uznania własnej tożsamości i egzystencji. Istotne jest także, aby nie czuł się jak obiekt, przedmiot, rzecz, podlegając zewnętrznym działaniom i zabiegom. Niewskazana jest opacznie rozumiana paternalistyczna opieka i litość, która w rzeczywistości nie zawiera szacunku, przeciwnie - jest skrywaną pogardą i poniżaniem. Wsparcie społeczne, które jest rozumiane jako dostępna człowiekowi pomoc z zewnątrz, nie byłoby możliwe, gdyby nie było wewnętrznej gotowości jednostki do jego przyjęcia i skorzystania z niego. Podobnie wyrażanie uczuć jest możliwe wtedy, gdy druga strona zaufała i uwierzyła w realną pomoc i możliwość zmiany. Człowiek musi sam dostrzec oferowane wsparcie i ocenić jego przydatność, aby móc włączyć się w proces inkluzji.

W pracy z osobami wykluczonymi w trudnych sytuacjach nie można zapominać, że wsparcie powinno stanowić przede wszystkim ludzki odruch. Pomoc słabszym i potrzebującym stanowi miarę kultury i dojrzałości konkretnej osoby, społeczeństw i narodów. Szacunek i akceptacja wyrażane przez otoczenie, poczucie bezpieczeństwa i własnej wartości oraz samoakceptacja wyzwalają subiektywne poczucie wartości dodanej we własnym życiu i kształtują właściwe relacje obu stron uczestniczących w wymianie wsparcia i procesie inkluzji społecznej.

Podstawą sukcesu jest społeczeństwo prezentujące zachowania o charakterze włączającym. To od jego reakcji, postaw, działań uzależniony jest efekt inkluzji. Z pewnością koniecznym warunkiem dla takiego stanu rzeczy są zmiany w świadomości społeczeństwa, a także u osób bezpośrednio zaangażowanych w realizację procesu włączania - nauczycieli, pracowników socjalnych, asystentów rodziny. W środowiskach o charakterze włączającym daje się zaobserwować konsensus co do wartości, jaką jest szacunek dla różnorodności ludzi. Nie musi on zawsze oznaczać braku napięć i sporów, ale istotne jest, aby wszelkie nieporozumienia w środowisku związane $\mathrm{z}$ brakiem tolerancji przekładały się na wysoki poziom współpracy we wspólnym rozwiązywaniu problemów. Z pewnością konieczne jest, aby w danych środowiskach lokalnych zadbać o rozwój włączającej kultury i budować sieć wsparcia na wartościach promujących różnorodność i włączanie. W działaniu tym nie do przecenienia jest rola osób, które najczęściej kontaktują się z wykluczonymi społecznie. W kształtowaniu nowego wizerunku środowiska lokalnego o charakterze włączającym to właśnie one odgrywają znaczącą rolę, są liderami, animatorami, ambasadorami nowego podejścia do osób wykluczonych, promują włączające praktyki na terenie danej miejscowości, a także budują związki 
pomiędzy osobami wykluczonymi a środowiskiem lokalnym. Osoby, które bezpośrednio zaangażowane są $\mathrm{w}$ pracę $\mathrm{z}$ wykluczonymi społecznie, a więc głównie pracownicy socjalni, asystenci rodziny, członkowie różnego typu organizacji pozarządowych podejmujących działania na rzecz osób wykluczonych lub zagrożonych wykluczeniem, niewątpliwie powinny posiadać umiejętności:

- diagnozowania sytuacji osoby wykluczonej z uwzględnieniem głównie jej potencjału, mocnych stron, indywidualnych zainteresowań, na których można oprzeć konkretne działania;

- rozwiązywania problemów oraz określenia, jakie kwalifikacje wymagają usprawnienia, wzmocnienia czy wręcz nauczenia;

- kształtowania u podopiecznego wewnętrznej motywacji do rozwijania umiejętności potrzebnych do funkcjonowania w środowisku;

- doceniania nawet najmniejszych pozytywnych form w zachowaniu podopiecznego;

- poznawania relacji rodzinnych i środowiskowych;

- nawiązywania kontaktów i współpracy z instytucjami funkcjonującymi na danym terenie;

- inicjowania działań integrujących wszystkich członków danego środowiska lokalnego, bez względu na ich przeszłość, dotychczasowe problemy związane z zachowaniem, odmienności kulturowe, specyfikę potrzeb itp.

O charakterze przebiegu i efektach procesu inkluzji społecznej decydują zarówno zasoby wewnętrzne, jak i zewnętrzne. Odwołując się do modelu dopasowania zasobów, można postawić tezę, że sukces inkluzji społecznej uzależniony jest od wzajemnego dopasowania wymogów środowiska i zdolności zaradczych jednostki. French i jego współpracownicy zakładali, że „środowisko i zasoby jednostki oddziałują na siebie nawzajem i że w tej interakcji należy szukać źródeł stresu" (Hobfoll 2006, s. 108). We wspomnianym modelu przyjęto następujące założenia:

„1. Człowiek dysponuje skończoną ilością zasobów.

2. Wymogom środowiska można sprostać za pomocą specyficznych zasobów.

3. Jeśli jednostka dysponuje wymaganymi zasobami, to jest w stanie zmienić bądź pokonać stres, a nawet w ogóle mu zapobiec" (Hobfoll 2006, s. 108).

\section{Relacyjny model inkluzji społecznej}

Analizując uwarunkowania wykluczenia i inkluzji społecznej, zauważamy, że w przebiegu owych procesów znaczącą rolę odgrywa stan zasobów wewnętrznych i zewnętrznych. Dostrzega się wzajemne przenikanie i uzupełnianie zasobów wewnętrznych i zewnętrznych jednostki. Poczynione obserwacje pozwoliły na opracowanie i przyjęcie założeń relacyjnego modelu inkluzji społecznej, rozumianego jako systematyczny proces wymiany, koordynacji, współpracy, transcendencji pomiędzy osobą, wspólnotą i kulturą, dającego szansę na integralny rozwój jednostki. Proponowane podejście opisują następujące tezy: 
- proces inkluzji społecznej jest rezultatem działania samej jednostki, jak również następstwem relacji zachodzących pomiędzy osobą wykluczoną a otoczeniem społecznym; jest wynikiem relacji intrapersonalnych osoby wykluczonej społecznie;

- charakter relacji zachodzących pomiędzy osobą wykluczoną a otoczeniem społecznym i nią samą można rozpatrywać z perspektywy efektu i procesu;

- istota relacji jednostki z otoczeniem i nią samą nie jest ustalona raz na zawsze, podlega przemianom wynikającym zarówno z przeobrażeń jednostki, jak i samego otoczenia społecznego;

- znaczącą rolę $\mathrm{w}$ interpretacji relacji $\mathrm{z}$ otoczeniem i samą sobą odgrywają zasoby wewnętrzne i zewnętrzne osoby wykluczonej społecznie;

- zasoby wewnętrzne osoby wykluczonej społecznie powinny być stale rozwijane, niezależnie od warunków i rodzaju niepełnosprawności; są determinowane zarówno jakością, jak i ilością relacji z otoczeniem, nią samą i układami społeczno-kulturowymi;

- zasoby wewnętrzne uzależnione są zarówno od doświadczenia (bogactwo relacji), jak też od pracy nad sobą, i wymagają nieustannego doskonalenia;

- zasoby wewnętrzne jednostki pozwalają na poradzenie sobie w relacjach społecznych interpretowanych przez jednostkę jako opresyjne, również charakterystycznych dla procesu inkluzji społecznej (w niektórych sytuacjach potrzebne jest wsparcie osób z zewnątrz, gdyż presja wywierana przez sieć społeczną jest niekiedy niemożliwa do odparcia przez samą jednostkę).

\section{Zakończenie}

W kontekście zaprezentowanych założeń relacyjnego modelu inkluzji społecznej zauważamy, że umiejętność poznania siebie (swoich zasobów wewnętrznych) jest ważnym elementem w życiu każdego człowieka. Nie do przecenienia są również zasoby zewnętrzne osoby wykluczonej społecznie, wśród których znaczącą rolę ogrywa wsparcie społeczne. Należy mieć świadomość, że za efektywny przebieg i wynik procesu inkluzji odpowiedzialne są obie grupy czynników. Aby stał się on faktem, muszą w tym procesie być obecne i aktywnie w nim uczestniczyć zarówno włączani, jak i włączający. Wszyscy powinni wykazywać inicjatywę w podejmowaniu różnych wspólnych działań w triadzie: osoba wykluczona - rodzina - środowisko lokalne, a także analizować i dostrzegać osiągnięcia, rezultaty, wymierne efekty tego współuczestnictwa.

Należy podkreślić konieczność prowadzenia działań inkluzyjnych w wymiarze osobowym, wspólnotowym i kulturowym. Tylko takie podejście stanowi szczególny rodzaj interwencji pomocowej dla jednostek, które nie są w stanie własnymi siłami, wspartymi na zasobach i potencjałach, zapewnić sobie szczęśliwej egzystencji. Model relacyjnej inkluzji jest szansą w obszarze integralności idei, ideałów, zasad, systemu i działań praktycznych, zadośćuczynienia efektom inkluzyjnym. 


\section{Bibliografia}

Bałandynowicz A., Pytka L., Zacharuk T. (2015). Edukacja inkluzyjna. Konteksty indywidualistyczne, wspólnotowe i transpersonalne. Siedlce: Wydawnictwo Uniwersytetu Przyrodniczo-Humanistycznego.

Bandura A. (1982). The assessment and predictive generality of self-percepts of efficacy. „Journal of Behavior Therapy and Experimental Psychiatry”, 13 (3), 195-199.

Beck U. (2012). Społeczeństwo światowego ryzyka. W poszukiwaniu utraconego bezpieczeństwa. Warszawa: Wydawnictwo Naukowe Scholar.

Bifulco A. (2007). Familial paterns of stress. W: Fink G. (red.). Encyclopedia of stress. Wyd. 2. New York: Academic Press.

Czapiński J. (200o). Indywidualna jakość życia. W: Czapiński J., Panek T. (red.). Diagnoza społeczna. Warunki i jakość życia Polaków oraz ich doświadczenia z reformami systemowymi po 10 latach transformacji. Warszawa: Rada Monitoringu Społecznego.

Czapiński J., Panek T. (red.). (2014). Diagnoza społeczna 2013. Warunki i jakość życia Polaków. Warszawa: Rada Monitoringu Społecznego, Centrum Rozwoju Zasobów Ludzkich, MPiPS.

Fidelus A. (2012). Determinanty readaptacji społecznej skazanych. Warszawa: Wydawnictwo UKSW.

Giddens A. (2004). Socjologia. Warszawa: PWN.

Grotowska-Leder J., Faliszek K. (red.). (2005). Ekskluzja i inkluzja społeczna. Diagnoza - uwarunkowania - kierunki działań. Toruń: Wydawnictwo Edukacyjne Akapit.

Hobfoll S.E. (2006). Stres, kultura i społeczność. Psychologia i filozofia stresu. Gdańsk: Gdańskie Wydawnictwo Psychologiczne.

Hobfoll S.E., Walfisch S. (1984). Coping with a threat to life. A longitudinal study of self-concept, social support, and psychological stress. „American Journal of Community Psychology", 12 (1), s. 87-100.

Konopczyński M. (2010). Nowa resocjalizacyjna szkoła warszawska - twórcza resocjalizacja $w$ kontekście kształcenia akademickiego. „Resocjalizacja Polska”, nr 1, s. 104.

Kowalak T. (1998). Marginalność i marginalizacja społeczna. Warszawa: Wydawnictwo Naukowe Scholar.

Lachowicz-Tabaczek K. (2004). Znaczenie naiwnych koncepcji w procesie percepcji i adaptacji do zmian. W: Maruszewski T. Adaptacja do zmian. Kolokwia Psychologiczne, t. 12. Warszawa: Wydawnictwo Instytutu Psychologii PAN.

Pospiszyl I. (2003). Ofiary chroniczne - przypadek czy konieczność. Warszawa: APS.

Pytka L. (2010). Pedagogika resocjalizacyjna w Uniwersytecie Warszawskim. Wczoraj, dziś, jutro? „Resocjalizacja Polska”, nr 1, s. 41.

Radlińska H. (1935). Stosunek wychowawcy do środowiska społecznego. Szkice z pedagogiki społecznej. Warszawa: Wydawnictwo Nasza Księgarnia. 
Sęk H., Cieślak R. (red.). (20o6). Wsparcie społeczne, stres i zdrowie. Warszawa: Wydawnictwo Naukowe PWN.

Teodorczyk T. (2005). Persona non grata: o wykluczeniach wewnętrznych i zewnętrznych. W: Orłowska M. (red.). Skazani na wykluczenie. Warszawa: APS.

\title{
THE ROLE OF INTERNAL AND EXTERNAL RESOURCES IN A RELATIONAL MODEL OF SOCIAL INCLUSION
}

\begin{abstract}
In this article, the reference was made to social exclusion as one of the many important issues relevant to people with disabilities. Reflecting on solutions which would allow to minimize the risks that generate social exclusion, while searching for the factors and ways to help strengthen the social inclusion process, an attempt was made to develop a relational model of social inclusion. It should be clearly stressed that these issues do not relate exclusively to individuals with disabilities. What is more, it would be an aberration to equate disability and social exclusion. It is a too far-reaching, stereotypical simplification. Unquestionably, such false concepts unfortunately are still present and should be refuted. In the discussion on the issue of exclusion and inclusion the reference has been made to a broad group of the excluded, to which unfortunately people with disabilities may also be counted in.
\end{abstract}

Key words: inclusion, exclusion, internal resources, external resources, relational, social support

Anna Fidelus - doktor habilitowana nauk społecznych, profesor nadzwyczajna Uniwersytetu Kardynała Stefana Wyszyńskiego w Warszawie (UKSW). Specjalista w zakresie resocjalizacji i readaptacji osób i rodzin wykluczonych społecznie. Analizuje kwestie uwarunkowań ekskluzji i inkluzji społecznej. Prowadzi badania z zakresu efektywności oddziaływań w placówkach socjoterapeutycznych i resocjalizacyjnych. Wybrane publikacje książkowe: Determinanty readaptacji społecznej skazanych (2012), Od stereotypu do wykluczenia (red.) (2014). Adres e-mail: a.fidelus@uksw.edu.pl. 